Key words: influenza $C$ virus/receptor-destroying enzyme/O-acetylesterase

\title{
Effect of Anti-haemagglutinin-esterase Glycoprotein Monoclonal Antibodies on the Receptor-destroying Activity of Influenza C Virus
}

\author{
By SHIGEMI HACHINOHE, KANETSU SUGAWARA, HIDEKAZU \\ NISHIMURA, FUMIO KITAME AND KIYOTO NAKAMURA* \\ Department of Bacteriology, Yamagata University School of Medicine, Iida-Nishi 2-2-2, \\ Yamagata 990-23, Japan
}

(Accepted 3 January 1989)

\begin{abstract}
SUMMARY
Five monoclonal antibodies $(\mathrm{J} 14, \mathrm{~J} 9, \mathrm{Q} 5, \mathrm{~K} 16, \mathrm{~S} 16)$, directed to three distinct antigenic sites (A-1, A-2, B-1) on the haemagglutinin-esterase glycoprotein of influenza $C$ virus, were analysed for their ability to inhibit the receptor-destroying enzyme (RDE) activity of the virus, utilizing various assay systems. The ability of influenza $\mathrm{C}$ virus to destroy the receptors on chicken erythrocytes was inhibited efficiently by the antibodies to site A-1 (J14, J9, Q5) but not by those to site A-2 (K16) and site B-1 (S16). Of the three antibodies to site A-1, J14 showed the highest inhibitory activity. Antibodies to sites A-1 and A-2 inhibited the ability of RDE to inactivate the haemagglutination inhibition activity of rat serum inhibitors, but the highest activity was observed again with J14. Thus the RDE site of influenza C virus may be located closest to the epitope recognized by $\mathrm{J} 14$. The removal of $O$-acetyl groups from either 9 $O$-acetyl- $N$-acetylneuraminic acid or $p$-nitrophenylacetate, caused by the viral RDE, was not prevented at all by any of the monoclonal antibodies tested. Furthermore, none of several polyclonal antiviral sera prepared in different animal species was able to block the hydrolysis of these small substrates, raising the possibility that the catalytic site of influenza $C$ viral RDE is antigenically silent.
\end{abstract}

Influenza $\mathrm{C}$ virions possess three biological activities, i.e. binding to the host cell receptors, receptor-destroying enzyme (RDE) and fusion with the host cell membrane. All of these activities reside in one surface glycoprotein, haemagglutinin-esterase (HE) (Kitame et al., 1982; Sugawara et al., 1985, 1986; Vlasak et al., 1987; Herrler et al., 1988; Formanowski \& MeierEwert, 1988). The $\mathrm{N}$ terminus of a smaller subunit of the HE protein contains a stretch of hydrophobic amino acid residues, and its sequence is homologous to the $\mathrm{N}$-terminal portion of the HA2 subunit of influenza A and B viruses (Herrler et al., 1981; Pfeifer \& Compans, 1984; Nakada et al., 1984), suggesting that this sequence is involved in membrane fusion. Muchmore $\&$ Varki (1987) have recently shown that treatment of influenza $C$ virions with diisopropyl fluorophosphate inactivates the RDE activity without influencing the receptor-binding activity, and have suggested that these two functions do not share the same site on the HE molecule. More information must be accumulated, however, to locate precisely the receptor-binding and receptor-destroying activities on the glycoprotein.

Recently, Herrler et al. $(1985 b)$ presented evidence that influenza C viral RDE is neuraminate- $O$-acetylesterase which releases acetyl residues from position C-9 of 9-O-acetyl- $N$ acetylneuraminic acid $\left(\mathrm{Neu} 5,9 \mathrm{Ac}_{2}\right)$. In this communication, the effect of five anti-HE monoclonal antibodies $(\mathrm{J} 14, \mathrm{~J} 9, \mathrm{Q} 5, \mathrm{~K} 16, \mathrm{~S} 16)$ on the acetylesterase activity of influenza $\mathrm{C}$ virus was studied with four different substrates to obtain information about its location on the HE molecule. The monoclonal antibodies against the HE glycoprotein of the C/Ann Arbor/1/50 


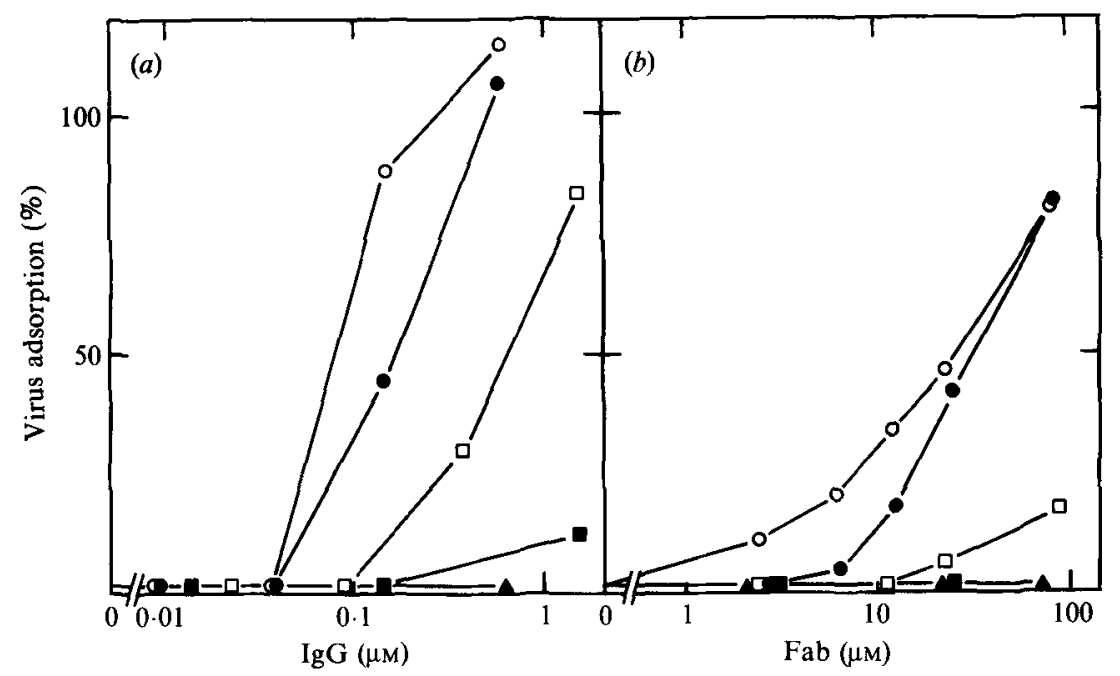

Fig. 1. Effect of monoclonal antibodies on the destruction of chicken erythrocyte receptors by influenza $\mathrm{C}$ virus. IgG molecules $(a)$ or Fab fragments $(b)$ from monoclonal antibody $\mathrm{J} 14(O), \mathrm{J} 9(O)$,

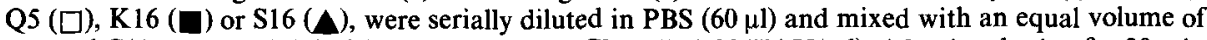
purified C/Ann Arbor/1/50 virions grown in MDCK cells (128 HAU/ml). After incubation for $30 \mathrm{~min}$ at room temperature, $100 \mu \mathrm{l}$ of the mixture was added to a chicken erythrocyte pellet $\left(6 \times 10^{6}\right.$ cells), and was allowed to act on the cellular receptors for $6 \mathrm{~h}$ at $37^{\circ} \mathrm{C}$. Cells were then washed in PBS, resuspended in $100 \mu \mathrm{l}$ of the buffer containing 4000 c.p.m. of $\left[{ }^{3} \mathrm{H}\right]$ glucosamine-labelled virions (approx. 150 c.p.m. $/ \mathrm{HAU}$ ) and further incubated at $0^{\circ} \mathrm{C}$ for $1 \mathrm{~h}$. After several washes in PBS, the level of virus adsoption was determined by counting the cell-associated radioactivity (Nishimura et al., 1988). Virus adsorption $(\%)$ refers to the amount of virus that was attached to the untreated cells. Each point represents the mean of two determinations. The Fab fragments were prepared by papain digestion of purified IgG molecules (Porter, 1959) followed by ion-exchange chromatography on DE52 (Hudson \& Hay, 1980).

strain were prepared as described previously (Hongo et al., 1986), and were used after purification by salting out with saturated ammonium sulphate. Our previous studies have shown that $\mathrm{J} 14, \mathrm{~J} 9$ and Q5, all of which are directed to antigenic site A-1, have high titres of haemagglutination inhibition (HI), haemolysis inhibition (HLI) and neutralization activities, and that $\mathrm{K} 16$, directed to site A-2, exhibits an extremely low level of $\mathrm{HI}$ activity though its HLI and neutralization activities are comparable to those of J14, J9 and Q5 (Sugawara et al., 1986, 1988). S16, which recognizes site B-1, has none of these biological activities.

The adsorption of radioactively labelled influenza $\mathrm{C}$ virions to chicken erythrocytes was greatly inhibited by prior treatment of cells with small amounts of unlabelled virus at $37^{\circ} \mathrm{C}$ (data not shown), reflecting the action of viral RDE on the erythrocyte receptors. The ability of monoclonal antibodies to block this effect of RDE was measured according to the procedures described in the legend of Fig. 1. Fig. 1 (a) shows that J14, J9 and Q5 strongly inhibited the destruction of erythrocyte receptors whereas no significant inhibition occurred with S16 and an extremely low level of inhibition occurred with $\mathrm{K} 16$, which suggests that the antigenic site A-1 is closer than sites A-2 and B-1 to the RDE site. It also appears likely that the RDE site is located nearest to the epitope recognized by $\mathrm{J} 14$ because the antibody showed the highest inhibitory activity. In addition, Fab fragments prepared from each monoclonal antibody were analysed for their ability to block the erythrocyte receptor-destroying activity of influenza $\mathrm{C}$ virus. Fig. $1(b)$ shows that the Fab fragments from J14, J9 and Q5 displayed significant levels of inhibition whereas those from $\mathrm{K} 16$ and S16 did not, and that of the former three antibodies, the fragments from $\mathrm{J} 14$ had the highest inhibitory activity, reinforcing the likelihood that the epitope recognized by $\mathrm{J} 14$ may be the closest to the site involved in receptor destruction. However, for 
Table 1. RDE inhibition titrations of monoclonal antibodies with rat serum inhibitors as substrates

\begin{tabular}{ccccc} 
Antigenic site & $\overbrace{\text { A-1 }}^{\text {Monoclonal antibody }}$ & Concentration $(\mu \mathrm{M})$ & $\begin{array}{c}\text { RDE inhibition } \\
(\text { units } / \text { ml)* }\end{array}$ \\
& J14 & IgG & 23 & 2560 \\
& J9 & Fab & 55 & 320 \\
& IgG & 25 & 1280 \\
& Q5 & Fab & 53 & 80 \\
& IgG & Fab & 25 & 640 \\
A-2 & K16 & IgG & 51 & 20 \\
& \multirow{3}{*}{ B-1 } & Fab & 33 & 640 \\
& S16 & IgG & 18 & 40 \\
& & Fab & 71 & $<\dagger$
\end{tabular}

\footnotetext{
* The values indicate the reciprocal of the highest antibody dilution that blocked the action of RDE and hence allowed the rat serum to inhibit haemagglutination.

† Less than 20.
}

any of the antibodies to antigenic site $A-1$, the molar concentration required to achieve a comparable level of inhibition was much higher in the presence of Fab than with their parent IgG. This could be accounted for by the RDE inhibition activity of native IgG molecules being caused predominantly by steric hindrance of substrate (erythrocyte receptor) access. However, we could not rule out an alternative possibility that the residual IgG, although not detected by SDS-PAGE (data not shown), might be responsible for the inhibitory activity of the Fab preparations.

Rat serum contains high titres of haemagglutination inhibitors specific for influenza $C$ virus (Styk, 1955, 1963), and treatment of the inhibitors with viral RDE inactivates their HI activity (Herrler et al., 1985a; Kitame et al., 1985). In order to measure the ability of each monoclonal antibody (IgG and Fab) to block the action of RDE, serial twofold dilutions of antibody in $125 \mu \mathrm{l}$ of phosphate-buffered saline, pH 7.2 (PBS) were mixed with an equal volume of the virus suspension containing 32 receptor-destroying enzyme units/ml of purified MDCK-grown virions, and the mixture was held at room temperature for $30 \mathrm{~min}$. Rat serum $(250 \mu \mathrm{l})$, diluted in PBS to give a titre of 4 haemagglutination inhibition units (HIU)/ $\mathrm{ml}$ was then added, and the reaction was allowed to proceed at $50^{\circ} \mathrm{C}$ for $2 \mathrm{~h}$. At the end of the incubation period, the mixture was boiled for $5 \mathrm{~min}$, which completely inactivated the HA and RDE activities of virus in addition to the $\mathrm{HI}$ activity of antibody but did not influence the $\mathrm{HI}$ activity of rat serum (data not shown). To determine whether the HI activity of rat serum was destroyed by viral RDE, 250 $\mu \mathrm{l}$ of a virus suspension containing 8 haemagglutination units (HAU) of MDCK-grown virions and $250 \mu \mathrm{l}$ of $1 \%$ chicken erythrocytes were added to each mixture, and the HA patterns were recorded after incubation for $1 \mathrm{~h}$ at $4^{\circ} \mathrm{C}$. As seen in Table 1, monoclonal antibodies (IgG) to antigenic site A-1 showed high levels of inhibitory activity whereas the antibody to site B-1 showed no activity. It was unexpected that the antibody to site A-2 should show an RDE inhibition titre as high as 640, raising the possibility that the RDE inhibition activity of K16 may be substrate-dependent, with an efficient inhibition against rat serum inhibitors and a lack of inhibition against chicken erythrocyte receptors. The Fab fragments of J14, J9, Q5 and K16 had detectable levels of RDE inhibition activity although their titres were eight- to 32-fold lower than those of $\operatorname{lgG}$. The Fab fragments of $S 16$, like their parent IgG, showed no inhibition.

The RDE of influenza $\mathrm{C}$ virus removes $\mathrm{O}$-acetyl residues from Neu5,9Ac $\mathrm{Ac}_{2}$ to produce $\mathrm{N}$ acetylneuraminic acid (Neu5Ac) (Herrler et al., 1985b). The ability of anti-HE monoclonal antibodies to prevent the conversion of Neu5,9 $\mathrm{Ac}_{2}$ into Neu5Ac was measured as follows. The antibody solution $(20 \mu \mathrm{l}$ in $0.01 \mathrm{M}$-sodium phosphate $\mathrm{pH} 7.2)$ was mixed with an equal volume of purified MDCK-grown virions $(256 \mathrm{HAU} / \mathrm{ml})$. After incubation for $30 \mathrm{~min}$ at room temperature, the substrate solution $(40 \mu \mathrm{l})$ containing $60 \mu \mathrm{g} / \mathrm{ml}$ of $\mathrm{Neu}_{5}, 9 \mathrm{Ac}_{2}$ in the same buffer 
Table 2. Effects of monoclonal and polyclonal antibodies on the removal of the O-acetyl group from Neu5,9Ac and $\mathrm{p}-N P A$ by influenza $C$ virus*

\begin{tabular}{|c|c|c|}
\hline \multirow[b]{2}{*}{ Antibody treatment } & \multicolumn{2}{|c|}{$O$-Acetyl removal from } \\
\hline & Neu5,9Ac $c_{2} \dagger$ & $p$-NPA $\ddagger$ \\
\hline None & $77 \pm 2$ & $0.29 \pm 0.03$ \\
\hline $\begin{array}{l}\text { Monoclonal antibodies§ } \\
\text { J14 } \\
\text { J9 } \\
\text { Q5 } \\
\text { K16 } \\
\text { S16 }\end{array}$ & $\begin{array}{l}74 \pm 8 \\
76 \pm 0 \\
75 \pm 8 \\
67 \pm 4 \\
69 \pm 7\end{array}$ & $\begin{array}{l}0 \cdot 35 \pm 0 \cdot 03 \\
0 \cdot 34 \pm 0 \cdot 02 \\
0 \cdot 36 \pm 0 \cdot 01 \\
0 \cdot 28 \pm 0.02 \\
0.32 \pm 0.03\end{array}$ \\
\hline $\begin{array}{l}\text { Polyclonal antibody\|l } \\
\text { Chicken } \\
\text { Rabbit } \\
\text { Pig } \\
\text { Mouse }\end{array}$ & $\begin{array}{l}87 \pm 5 \\
87 \pm 3 \\
74 \pm 3 \\
85 \pm 1\end{array}$ & $\begin{array}{l}0.35 \pm 0.03 \\
0.31 \pm 0.05 \\
0.34 \pm 0.02 \\
0.33 \pm 0.01\end{array}$ \\
\hline
\end{tabular}

* Triplicate samples were used for each assay.

+ Percentage of Neu5Ac; [Neu5Ac/(Neu5,9Ac $2+$ Neu5Ac)] $\times 100 ;($ mean \pm S.D. $)$.

$\ddagger$ Absorbance at $400 \mathrm{~nm}$ (mean \pm S.D.). Background values (the absorbance of the reaction mixtures from which influenza $C$ virions were omitted) were subtracted.

$\S$ Monocional antibodies were all used at $1 \mathrm{mg} / \mathrm{ml}$.

\|The HI titres of IgG molecules from chicken, rabbit, pig and mouse antisera were $569,368,151$ and 1164 $\mathrm{HIU} / \mathrm{mg}$ protein, respectively, and they were used at the following concentrations respectively: $9 \mathrm{mg} / \mathrm{ml}, 14$ $\mathrm{mg} / \mathrm{ml}, 34 \mathrm{mg} / \mathrm{ml}, 4 \cdot 4 \mathrm{mg} / \mathrm{ml}$.

was added and allowed to react at $37^{\circ} \mathrm{C}$ for $5 \mathrm{~h}$. The reaction was stopped by chilling on ice, and the mixture was filtered through an Ultrafree-C3GC membrane (Japan Millipore) to remove virus particles and antibody molecules. To assess the extent of conversion from Neu5, $9 \mathrm{Ac}_{2}$ to Neu $5 \mathrm{Ac}$, the filtrate $(20 \mu \mathrm{l})$ was analysed by HPLC using an anion exchange resin, Chemcosorb 7-SAX (Chemco Scientific Co.) as described by Diaz \& Varki (1985). Table 2 shows that no significant inhibition was observed with any of the antibodies tested at a concentration of 1 $\mathrm{mg} / \mathrm{ml}$. Inhibition of the removal of the $O$-acetyl group from $\mathrm{Neu} 5,9 \mathrm{Ac}_{2}$ was also undetectable even when the concentration of $\mathrm{J} 14$ was increased to $100 \mathrm{mg} / \mathrm{ml}$ (data not shown). These results could be explained by a lack of immunogenicity at the catalytic site of influenza $\mathrm{C}$ viral acetylesterase. To examine this possibility, similar experiments were carried out with antiviral polyclonal antibodies prepared in several different animal species; little or no inhibition was observed (Table 2).

Recently, Vlasak et al. (1987) revealed that a synthetic acetylesterase substrate, $p$ nitrophenylacetate ( $p$-NPA), was hydrolysed by influenza C viral RDE. In an experiment to analyse the ability of monoclonal and polyclonal antibodies to block this effect of RDE, the antibody solution ( $50 \mu \mathrm{l}$ in PBS) was mixed with an equal volume of purified MDCK-grown virions $(30 \mu \mathrm{g} / \mathrm{ml}$ in PBS), and the mixture was kept at room temperature for $30 \mathrm{~min}$. The enzyme reaction was then initiated by the addition of $800 \mu \mathrm{l}$ PBS and $100 \mu 1 \mathrm{p}$-NPA ( $1 \mathrm{mM}$ in PBS containing $1 \%$ acetonitrile), and the extent of hydrolysis was determined after incubation at $37^{\circ} \mathrm{C}$ for $1 \mathrm{~h}$ by measuring the absorbance at $400 \mathrm{~nm}$ (Kezdy \& Bender, 1962). Our preliminary study showed that at this time point the reaction was proceeding at a linear rate. As seen in Table 2 , the enzyme activity against $p$-NPA was not significantly inhibited by any of the monoclonal and polyclonal antibodies tested. The failure of anti-HE monoclonal and antiviral polyclonal antibodies to inhibit the viral acetylesterase reacting with two different small substrates (Neu5,9Ac $c_{2}, p$-NPA) strongly suggests that the catalytic site of the enzyme is devoid of immunogenicity, as is the case with the neuraminidase of influenza $A$ and $B$ viruses (Fazekas de St. Groth, 1963).

There are only two reports in which the effect of anti-HE monoclonal antibodies on influenza $\mathrm{C}$ viral RDE has been studied. Vlasak et al. (1987) reported that the release of acetate from 
bovine submandibulary mucin by the virus was not inhibited by any of five HE-specific monoclonal antibodies, and Herrler et al. (1988) showed that it was inhibited partially (26 to $52 \%$ ) by four of eight anti-HE monoclonal antibodies. The data presented in this study suggest that the site responsible for the acetylesterase activity of influenza $\mathrm{C}$ virus is located close to the antigenic site A-1, and particularly close to the epitope recognized by monoclonal antibody $\mathrm{J} 14$. We have previously shown that the epitope recognized by this antibody is conserved among all of 15 human influenza $C$ strains isolated between 1947 and 1983 whereas those recognized by the other antibodies, to sites A-1 and A-2, undergo considerable change (Sugawara et al., 1986, 1988). This suggests that the integrity of the epitope that recognizes J14 may be required for the biological functions of the HE glycoprotein. Furthermore, we found that all of the escape mutants selected in the presence of J14 could be distinguished by their RDE properties from their parent virus as well as from mutants selected with each of the other antibodies (see below for details). Thus it is likely that the active site of the acetylesterase and the epitope recognized by $\mathrm{J} 14$ are located close to each other on the HE glycoprotein molecule. Sequencing of the HE gene of the J14-escape mutants will therefore provide important information concerning the location of the active site.

As described above, Muchmore \& Varki (1987) recently suggested the involvement of two separate sites in the haemagglutinating and acetylesterase activities of influenza $\mathrm{C}$ virus. However, no evidence to support this idea has been obtained in this study. The RDE inhibition test with either chicken erythrocytes or rat serum inhibitors showed that the acetylesterase activity was inhibited by HI-positive monoclonal antibodies but not by HI-negative ones. The only exception was that hydrolysis of rat serum inhibitors was inhibited considerably by K16 which has little HI activity; this could be explained if the binding of K 16 to HE protein sterically interfered with the access of virus to the inhibitors and not to the erythrocyte receptors. We have also observed that when chicken erythrocytes were treated at $37^{\circ} \mathrm{C}$ for $2 \mathrm{~h}$ with a small amount of the escape mutant selected with $\mathrm{J} 14$, the cells became non-agglutinable by either the mutant or its parent virus. In contrast, erythrocytes pretreated with the parent virus, though not agglutinated by the parent virus itself, could still be agglutinated by the J 14-resistant mutant (K. Nakamura et al., unpublished results). These preliminary observations strongly suggest that the specificity of both receptor recognition and receptor destruction by influenza $\mathrm{C}$ virus can be influenced by amino acid change(s) in the region corresponding to the epitope recognized by J14. It appears likely, therefore, that the sites involved in these two biological activities, even if distinct, are located very close to each other within or near this epitope.

This work was supported by a Grant-in-Aid for Scientific Research from the Ministry of Education, Science and Culture, Japan, the Naito Foundation and a Grant-in-Aid from the Japan Medical Association.

\section{REFERENCES}

DIAZ, S. \& VARKI, A. (1985). Metabolic labeling of sialic acids in tissue culture cell lines: methods to identify substituted and modified radioactive neuraminic acids. Analytical Biochemistry 150, 32-46.

FAZRKAS DE ST. GROTH, S. (1963). Steric inhibition: neutralization of a virus-borne enzyme. Annals of the New York Academy of Sciences 103, 674-687.

FORMANOWSKI, F. \& MEIER-EWERT, H. (1988). Isolation of the influenza C virus glycoprotein in a soluble form by bromelain digestion. Virus Research 10, 177-192.

HERRLER, G., NAGELE, A., MEIER-EWERT, H., BHOWN, A. S. \& COMPANS, R. W. (1981). Isolation and structural analysis of influenza $C$ virus glycoproteins. Virology 113, 439-451.

HERRLER, G., GEYER, R., MÜLLER, H.-P., STIRM, S. \& KLENK, H.-D. (1985a). Rat $\alpha_{1}$-macroglobulin inhibits hemagglutination by influenza $C$ virus. Virus Research 2, 183-192.

HERRLER, G., ROTT, R., KLENK, H.-D., MÜLLER, H.-P., SHUKLA, A. K. \& SCHAUER, R. (1985b). The receptor-destroying enzyme of influenza $C$ virus is neuraminate- $O$-acetylesterase. EMBO Journal 4, 1503-1506.

HERRLER, G., DÜRKOP, 1., BECHT, H. \& KLENK, H.-D. (1988). The glycoprotein of influenza C virus is the haemagglutinin, esterase and fusion factor. Journal of General Virology 69, 839-846.

HONGO, S., SUGAWARA, K., HOMMA, M. \& NAKAMURA, K. (1986). The functions of oligosaccharide chains associated with influenza $\mathrm{C}$ viral glycoproteins. Il. The role of carbohydrates in the antigenic properties of influenza $\mathrm{C}$ viral glycoproteins. Archives of Virology 89, 189-201.

HUDSON, L. \& HAY, F. C. (1980). Cleavage of IgG by proteolytic enzymes: papain digestion. In Practical Immunology, pp. 192-193. Oxford: Blackwell. 
KEZDY, F. J. \& BENDER, M. L. (1962). The kinetics of the $\alpha$-chymotrypsin-catalyzed hydrolysis of $p$-nitrophenyl acetate. Biochemistry 1, 1097-1106.

Kitame, F., SUgaWARA, K., OHWADA, K. \& HOMMA, M. (1982). Proteolytic activation of hemolysis and fusion by influenza $C$ virus. Archives of Virology 73, 357-361.

KITAME, F., NAKAMURA, K., SAITO, A., SINOHARA, H. \& HOMMA, M. (1985). Isolation and characterization of influenza $C$ virus inhibitor in rat serum. Virus Research 3, 231-244.

MUCHMORE, E. A. \& VARKI, A. (1987). Selective inactivation of influenza $\mathrm{C}$ esterase: a probe for detecting 9-Oacetylated sialic acids. Science 236, 1293-1295.

NAKADA, S., CREAGER, R. S., KRYSTAL, M., AARONSON, R. P. \& PALESE, P. (1984). Influenza C virus hemagglutinin: comparison with influenza A and B virus hemagglutinins. Journal of Virology 50, 118-124.

NISHimURA, H., SUGawara, K., KITAME, F. \& NAKAMURA, K. (1988). Attachment of influenza C virus to human erythrocytes. Journal of General Virology 69, 2545-2553.

PFEIFER, J. B. \& COMPANS, R. W. (1984). Structure of the influenza C glycoprotein gene as determined from cloned DNA. Virus Research 1, 281-296.

PORTER, R. P. (1959). The hydrolysis of rabbit $\gamma$-globulin and antibodies with crystalline papain. Biochemical Journal 73, 119-126.

STYK, B. (1955). Non-specific inhibitors in normal rat serum for the influenza $\mathrm{C}$ type virus. Folia biologica 1 , 207-213.

STYK, B. (1963). Effect of some inhibitor-destroying substances on the nonspecific inhibitor of C influenza virus present in normal rat serum. Acta virologica 7, 88-89.

SUGAWARA, K., KITAME, F., HOMMA, M. \& NAKAMURA, K. (1985). An assay for the receptor-destroying activity of influenza $C$ virus. Microbiology and Immunology 29, 1207-1217.

SUGAWARA, K., NISHIMURA, H., KITAME, F. \& NAKAMURA, K. (1986). Antigenic variation among human strains of influenza $C$ virus detected with monoclonal antibodies to gp88 glycoprotein. Virus Research 6, 27-32.

SUGAWARA, K., KITAME, F., NISHIMURA, H. \& NAKAMURA, K. (1988). Operational and topological analysis of antigenic sites on influenza $\mathrm{C}$ virus glycoprotein and their dependence on glycosylation. Journal of General Virology 69, 537-547.

VLASAK, R., KRYSTAL, M., NACHT, M. \& PALESE, P. (1987). The influenza C virus glycoprotein (HE) exhibits receptorbinding (hemagglutinin) and receptor-destroying (esterase) activities. Virology 160, 419-425.

(Received 2 August 1988) 